\title{
A diachronic analysis of visiblement/visiblemente: contemporary false-friends*
}

\author{
Sonia Gómez-Jordana (Madrid)
}

\begin{abstract}
The aim of this paper is to establish how the French adverb visiblement has evolved, and to find the most accurate translations of this adverb in Spanish. Dictionaries tend to give literal translations, whereby visiblement is translated as visiblemente. A diachronic analysis of this adverb will enable us to see whether they are indeed false-friends. In Old French and in Preclassical French, it was used as a clause element adverb, before being used as a disjunct adverb from the $17^{\text {th }}$ century onwards. Eventually, it goes on to appear by itself, or, accompanying an affirmative, like oui, in the $20^{\text {th }}$ century. We will demonstrate that the adverb undergoes a process of pragmaticalisation as described by Dostie (2004), with the adverb becoming more subjective, going from a literal sense, to a disjunct or pragmatic adverb. Nevertheless, in Spanish, since Old Spanish until nowadays, there are almost no examples other than its use as a clause element adverb. That's the reason why we cannot propose a literal translation of the adverb.
\end{abstract}

\section{$1 \quad$ Introduction}

Visiblement is an evidential adverb, concerned with the source of information. The question that will concern us here, is to establish how the adverb visiblement has evolved, and to establish the most accurate translations of this adverb in Spanish. Dictionaries tend to give literal translations, whereby visiblement is translated as visiblemente, in the same way that justement is translated as justamente and décidément as decididamente. A diachronic analysis of this adverb will enable us to see whether they are indeed false-friends. We will make use of corpora compiled mainly from Frantext databases, as well as databases from oral corpora such as CLAPI (French), and the Spanish language databases CORDE and CREA (RAE).

\section{Visiblement: Diachronic Evolution: from the clause element adverb to the pragmatic adverb}

Dictionaries, including historical ones, trace the adverb visiblement back to Old French. According to dictionary definitions, visiblement is given to mean both 'in a visible way' as

\footnotetext{
* Acknowledgements: Research for this article was supported by a research project on "Enunciation and Orality Marks in French Historical Linguistics" from the Ministerio de Economía y Competitividad, Spain, (Research Project FFI2017-84404-P).
}

Linguistik online 92, 5/18 - http://dx.doi.org/10.13092/lo.92.4504

CC by 3.0 
well as 'in an obvious, manifest way'. Both of these meanings apply in Modern French. We will now analyse what kind of adverb visiblement corresponds to, and how its use and meaning have evolved throughout the centuries. We will look at the type of evidence and sources that prompt the speaker to utter visiblement, as well as studying the usage.

According to contextual and dictionary uses, in Old French and Middle French, as well as in Pre-classical French, throughout the $16^{\text {th }}$ century, the adverb visiblement is used as a clause element adverb with the meaning 'in a visible way'. For example, the Dictionnaire de moyen français (DMLF) proposes this definition: De manière visible, perceptible par la vue. The Dictionnaire de Richelet (1680) shows this definition of the adverb: D'une manière visible, clairement, manifestement.

1. N'onques ne fu, c'est chose voire,

A veoir plus bel edefice,

Car, tant fu par grant artefice

Fondé et fait si soubtilment

Qu'il sembloit tout visiblement

A toutes gens grans et menues

Que le sommet touchiast les nues

Christine de Pizan, Le livre de la Mutation de Fortune, 1400, p.109

'It seemed visibly to everybody, large and small, that the summit touched the skies.' ${ }^{1}$

2. Bons et mauvais le verront visiblement en chair.

Raoule de Presles, Cité de Dieu, éd.1486, (quoted in Godefroy)

'Both good and bad people will see it visibly in the flesh.'

In several instances the adverb is preceded by verbs such as voir, paraitre or apparaitre:

3. Et vraiement il a la vne grant merueille; car on voit visiblement maintes fois la terre de sa tombe croller et mouuoir par desseure et la pouldre, tout ainsi que il eust vn homme vif par dessoubz qui le remeust;

Jean de Mandeville, Voyages, 1360, p. 240

'As he sees, visibly, several times, the earth tremble from its tomb.'

4. et apres il les metroit en vn plus bel paradis assez, la ou il verroient visiblement Dieu de nature en sa maieste et en sa gloire.

Jean de Mandeville, Voyages, 1360, p. 389

'There where they will see God visibly, in his majesty and glory.

5. où il le dit quant au corps que ces bestes ou ces esperis prennent quant ilz veullent apparoir visiblement à aucun, quar ilz espessissent l'air et le figurent comme il leur plaist.

Presle Raoul de, La Cité de Dieu de Saint Augustin, vol.1, t 1, 1371-1375, p.141

'When they want to appear to someone visibly'

\footnotetext{
${ }^{1}$ The adverb visiblement/visiblemente has been rendered literally as visibly in the English translations.
} 
6. Il vit, ce disoit il, apparoir, presentement et visiblement, devant son lit une serpente, grande et grosse merveilleusement.

Jean D'Arras, Mélusine, 1392, p. 308

'He claims to have seen a snake appear in front of his bed in a present and visible manner (and visibly).'

7. Si n'oz pas la esté gramment, Quant j'apperceu visiblement La royne de tout meseur, De qui le mouvement non seur Met tout le monde en grant racune.

Christine De Pisan, Le livre du chemin de long estude, 1402-1403, p.96

'When I visibly noticed the queen appear.'

8. Ma meschinete, saiches que, non obstant que tes yeulx foibles en me puissent clerement veoir pour leur groisseur, que je suis celle qui nuement et visiblement s'apparu ou temps de l'exil et de sa tribulacion a mon chier amé filz Bouece le tres souffisant philosophe,

Christine De Pisan, Le livre de l'advision christine, 1405, p. 94

'I am the one who has appeared without any addition and visibly.'

9. Et que ceste vie soit sur toutes autres agreable a Dieu est apparu maintes foiz au monde visiblement, si que il est escript de pluseurs saints et sainctes contemplatifs qui ont esté veus quant ilz estoient en leur contemplacion eslevéz dessus terre tres hault...

Christine De Pisan, Le Livre des trois vertus, 1405, p. 24

'(...) has visibly appeared several times in the world.'

10. Milles personnes qui lors estoyent la, Tant de noz gens que ceulx de Genes virent Visiblement luy advenir cela.

La Vigne André de, Le voyage de Naples, 1495, p. 177

'Our people, as well as Genes', turned visibly when that happened to him.'

11. la feste du premier martir, lendemain de Noël, je viz visiblement de mes yeulx la tres sacrée majesté imperialle,

Lamaire De Belges Jean, La Concorde du genre humain, 1509, p. 71

'(...) I see visibly, with my own eyes, his sacred imperial majesty.'

By the time we reach Middle French, the term has already taken on the meaning of manifestly, as in:

12. Nous congnoissons visiblement Que ce n'est pas bien nostre cas.

(Myst. siège Orléans H. c. 1480-1500. 335).

'We know that it is visibly not our case.'

In both Old French and Middle French visiblement is a clause element adverb, which modifies the term it goes with. This is emphasized in several instances by degree markers as tout- il sembloit tout visiblement/or by pairing the adverb with another clause element adverb: Il vit (...) apparoir, presentement et visiblement, devant son lit une serpent.

From the $17^{\text {th }}$ century onwards, in Classical French, the adverb appears more and more frequently, still as a clause element adverb, and with the meaning of 'manifestement, clairement' as in: 
13. On sçait visiblement qu'il veut faire donner à ses gens de guerre, on nous asseure neantmoins de la paix.

Lucinge René de, Les Occurrences de la paix de Lyon, 1601, p. 35

'One knew visibly that he wanted to wage war on these people, while assuring us hewanted peace.'

Here, the verb is no longer a verb of perception such as voir, but rather a factual verb, savoir. The adverb could be substituted here by manifestement, clairement.

In 1660, we find the first instance in Frantext of the adverb in sentence-initial position ${ }^{2}$ :

14. (...) aprés, seigneur, aprés tant de promesses qui nous avoient unis aveque toy, d'où vient que sans égard en un seul jour tu laisses ton fils, nostre sauveur, ton oint et nostre roy? Visiblement ta grace l'abandonne, il est battu du sort de toutes parts.

'Your grace visibly abandons him, he is beaten by fate on all sides.'

Racan Honorat de, Les Psaumes, 1660, p.236

It is no longer a clause element adverb. The order in the sentence is flexible:

Ta grace l'abandonne, visiblement.

'Your grace visibly abandons him.'

Unlike with clause element adverbs, it cannot be denied or questioned:

*Est-ce visiblement que ta grace l'abandonne? 'Does your grace visibly abandon him?'

Neither can it be used emphatically:

*C'est visiblement que ta grace l'abandonne. 'Visibly, your grace abandons him.'

Finally, the adverb cannot be used as an adverb of degree:

???Très/ tout visiblement ta grace l'abandonne. 'Very visibly your grace abandons him.'

We are dealing with a sentential adverb, meaning 'It is evident, it is clear that your grace abandons you'. Nevertheless, this use is still rare in the $17^{\text {th }}$ century. We will find more and more instances, especially from the $18^{\text {th }}$ century onwards:

15. Ainsi lorsque nous lui disons: ne nous induisez pas en tentation: visiblement il faut entendre: en permettez pas que nous y entrions.

Bossuet Jacques-Bénigne, Méditations sur l'Évangile, 1704, p. 96

'Thus when we tell him: lead us not into temptation: we must visibly understand: do not allow us to enter into it.'

16. (...) de dire qu'il n'y ait pas un rapport manifeste dans ces paroles, que l'une n'est pas la préparation et la promesse de l'autre, et que la dernière n'est pas l'accomplissement de celle qui a précédé, c'est vouloir dire que Jésus-Christ qui est la sagesse éternelle parle et agit au hazard. Visiblement il a parlé en St Jean pour préparer l'institution de l'eucharistie

Bossuet Jacques-Bénigne, Méditations sur l'Évangile, 1704, p. 388

'Visibly, in Saint John, he is talking about preparing the institution of the eucharist.'

\footnotetext{
2 There is no mention in the dictionnaries about the adverb position.
} 
17. Mais puisque manger et boire à la foy, c'est la mesme chose, Jésus-Christ ne se seroit pas arresté jusqu'à quatre fois réitérées à distinguer le manger d'avec le boire, ni la viande d'avec le breuvage, s'il n'avoit pas regardé à autre chose.

Visiblement donc il a regardé aux paroles de l'institution où manger, c'est prendre par la bouche, où boire, c'est boire dans une coupe et en avaler la liqueur.

'So visibly, he is condidering the word of the institution, where eating means taking something via the mouth and drinking means drinking from a cup while tasting the liquid.'

Bossuet Jacques-Bénigne, Méditations sur l'Évangile, 1704, p. 390

In all of these instances, we are dealing with a disjunct adverb rather than a clause element adverb. What this means is that right up to the present, the adverb is used both as a disjunct adverb, as well as a clause element adverb, although the second usage has been in decline in recent years. Therefore, from the mid- $19^{\text {th }}$ century onwards, even though the clause element adverb is very widespread, we begin to see more and more instances of the disjunct adverb, both at the beginning and in the middle of the sentence.

\section{Nos animaux, visiblement, restaient inconsolables du départ de mon père.}

Michelet Jules, L'Oiseau, 1856, p. XXXIII

'Our animals are visibly inconsolable following my father's departure.'

From the mid- $19^{\text {th }}$ century onwards, we find the adverb standing alone (in absolute position):

19. Maintentant it était trop tard. Visiblement.

- Vous avez toujours pu résister à vos désirs, dit-elle.

Vian Boris, L'Herbe rouge, 1950, p. 153

'Now it was too late. Visibly.'

We also find the adverb accompanying oui.

20. Être gaulliste, aimer de Gaulle comme nous l'aimons c'est visiblement pour lui le comble de l'inacceptable. Visiblement oui, puisque ses traits sont altérés.

Maurac Claude, L'Oncle Marcel, 1988, p. 273

'Being a De Gaulle supporter or loving De Gaulle as we loved him, was visibly totally unacceptable to him. This was visibly the case as his facial features changed.'

In oral corpora, we find instances of visiblement oui, where the oui could even be omitted without resulting in any loss in meaning:

21. - Elle rentrée chez elle là.

- Oui visiblement oui c'est ça hein Fabien elle est rentrée chez elle. CLAPI

'Yes, visibly that is the case Fabien.' (conversation in a cheese shop).

In the 15 examples in the CLAPI oral corpus, there is only one instance of visiblement as a clause element adverb. 


\section{Evidence, sources and usage}

\subsection{Evidence}

Up until the $18^{\text {th }}$ century, most instances of visiblement are based exclusively on visual evidence of the speaker, allowing him to state visiblement $p$. In all instances where it is a clause element adverb, the evidence is visual.

22. Tu demandes a veoir celle Qui enfanta, vierge pucelle, En sa glorieuse biauté: Aroies tu la voulenté Que l'ueil senestre on te crevast, Par si qu'elle a toy se monstrast Visiblement?

Anonyme, Miracle de l'empereur Julien, 1351, p. 217

'Would you have someone poke out your eyes as she visibly showed herself to you?'

23. Mais combien quil soient saufs, pour ce en sont il mie senz paour, quant ilz voient visiblement les ennemis entour euls, qui leur font diuers assaus et de menaces en lair et en terre, des coups de tonnoirre et de tempestes.

Jean De Mandeville, Voyages, 1360, p. 390

'When they see their enemies visibly all around them.'

24. la feste du premier martir, lendemain de Noël, je viz visiblement de mes yeulx la tres sacrée majesté imperialle,

Lemaire De Belges, Jean, La Concorde du genre humain, 1509, p. 71

'on the day of the feast of the first martyr, the day after Christmas, I saw visibly, with my own eyes, his holy imperial majesty.'

25. Cependant sa santé continuant à s'altérer tous les jours, il parut visiblement sur son visage qu'elle souffroit quelque douleur dont elle ne se plaignoit point.

Prévost L'Abbé, Le Philosophe anglois ou Histoire de Monsieur Cleveland, fils naturel de Cromwell: t. 1-3, 1731, p. 75

'Nevertheless his health continued to change every day. It showed visibly on his face.'

26. La tristesse étoit peinte si visiblement sur mon visage, que madame en prit occasion de le faire remarquer au roy...

Prévost L'Abbé, Le Philisophe anglois ou Histoire de Monsieur Cleveland, fils naturel de Cromwell: t. 1-3, 1731, p. 227

'Sadness was so visibly etched on my face that madame took it upon herself to point this out to the king'

27. (...) deux indices pouvait me mettre sur la voie: la qualité du papier, visiblement de fabrique anglaise, et l'empreinte du cachet.

Jouy Étienne de, L'Hermite de la Chaussée-d'Antin, 1812, p. 105

'the quality of the paper, visibly manufactured in England' 
28. Trois procédés quand une femme sort du piano: si l'on est loin, levez vos mains visiblement pour applaudir: c'est un moyen de montrer vos boutons de manche et la jolie façon dont vous êtes gantés.

Taine Hippolyte, Notes sur Paris: Vie et opinions de M. Frédéric Thomas Graindorge, 1867 , p. 55

'Three procedures when a lady finishes playing the piano: if one is far away one should raise one's hands visibly to applaud'

Where the adverb has the meaning of 'manifestement', the speaker draws from visual evidence in order to be able to state visiblement. Therefore, in the following extract:

29. Nous estions cependant bien endemenez, nous n'avions pas un soldat, nous avions pris la guerre pour nostre part. Le Roy estoit porté à Lyon, il passe à Grenoble. On sçait visiblement qu'il veut faire donner à ses gens de guerre, on nous asseure neantmoins de la paix.

Licinge René de, Les Occurrences de la paix de Lyon, 1601, p. 35

'We knew visibly that he wanted to wage war on these people while assuring them peace.'

The speaker bases his statement on visual evidence, which could be substituted by: d'après ce que j'ai vu je peux affirmer qu'on sait qu'il veut faire donner à ses gens de guerre.

In 1660 we find the first instance of visiblement in sentence-initial position, as a disjunct adverb. The evidence is still visual and it is the speaker, who, upon seeing evidence $\mathrm{x}$ can state visiblement $p$ :

30. (...) aprés, siegneur, aprés tant de promesses qui nous avoient unis aveque toy, d'où vient que sans égard en un seul jour tu laisses ton fils, nostre sauveur, ton oint et roy?

Visiblement ta grace l'abandonne, il est battu du sort de toutes parts.

Racan Honorat de, Les Psaumes, 1660, p. 236

'Visibly, your grace abandons him, he is defeated by fate on all sides.'

In this instance, the speaker has seen how a father has left his son in one day, evidence which allows him to state ta grace l'abandonne. Visiblement reinforces the segment $\mathrm{p}$, ta grace l'abandonne, precisely because it is something which is supported by what the speaker has been able to see with his own eyes. Visiblement serves to reinforce, or, in the words of Ducrot (1995), it is a realising modifier (modificateur réalisant), in that it concedes greater argumentative strength to the segment claiming to have proof, in this case, visual proof. On a scale of certainty, visiblement would appear below réellement and above probablement, apparemment and certainement. The following example supports this scale of certainty.

31. Je n'en sais rien, mais toujours est-il que, dans le microcosme de notre avion, le sexe fort se distingue visiblement - sinon réellement - du sexe faible. Il y a bel et bien, d'un côté, les $<<$ jupes $>>$ déliquescentes et, de l'autre, les $<<$ culottes $>>$ résistantes...

Dorin Françoise, Les jupes-culottes, 1984, p. 238

'it still appears that in the microcosm of our plane, the stronger sex stands out visibly from the weaker sex.' 


\section{From visual evidence to deduction:}

However, from the $18^{\text {th }}$ century onwards, we see a process of semantic evolution. Beside instances where visblement stems from exclusively visual evidence, it also starts to appear in response to evidence that is not purely visual. We start to see instances where there is an inductive process. The adverb effectively highlights the relationship between evidence $\mathrm{X}$, presented as proof of a certain conclusion, and this conclusion. The speaker assumes this deduction to be evident and appeals to his interlocutor to accept it. Here are a few examples:

32. Toutes les facultés communes aux deux sexes en leur sont pas également partagées, mais prises en tout elles se compensent ; la femme vaut mieux comme femme et moins comme homme ; partout où elle veut usurper les nôtres elle reste au-dessous de nous. On en peut répondre à cette vérité générale que par des exceptions ; constante manière d'argumenter des galans partisans du beau-sexe. Cultiver dans les femmes les qualités de l'homme et négliger celles qui leur sont propres, c'est donc visiblement travailler à leur préjudice...

Rousseau J.J., Émile ou De l'éducation, 1762, p. 701

'If we cultivate in women those qualities which pertain to men, while neglecting their female traits, then we visibly do them a disservice.'

The speaker puts forward his arguments, everything he has stated, as evidence, as proof in support of a conclusion. In this case, the speaker presents La femme vaut mieux comme femme et moins comme homme / partout où elle veut usurper les nôtres (nos facultés) elle reste audessous de nous, as evidence, as proof, leading to a conclusion, such as cultiver dans les femmes les qualités de l'homme et négliger celles qui leur sont propres, c'est donc travailler à leur préjudice, the adverb visiblement could be omitted without any loss in meaning. Nonetheless it serves to highlight the deductive relationship between the evidence stated by the speaker, and the conclusion he draws from it. The adverb reinforces this conclusion, by saying something like, according to what I have just said, or, according to what I have just shown, it is visible, it is manifest that $\mathrm{p}$. Thanks to the adverb visiblement, the speaker not only takes responsibility for the relation between evidence and conclusion, but he is also presenting it as something evident and as something that should be admitted by his interlocutor. It is as if the speaker were saying "you cannot deny this":

Cultiver dans les femmes les qualités de l'homme et négliger celles qui leur sont propres, c'est donc?? probablement/?? apparemment/?? peut-être travailler à leur préjudice, vous en pouvez pas dire le contraire.

Several instances juxtapose donc and visiblement. We can observe this in the following example:

33. César (...) ne lui odjecte-t-il pas que (...) ce n'est point punir un criminel que de le fairemourir, que la mort n'est rien, que c'est seulement la fin de nos maux, que c'est un moment plus heureux que fatal? Cicéron et tout le sénat ne se rendent-ils pas à ces raisons? Les vainqueurs et législateurs de l'univers connu formaient donc visiblement une société d'hommes qui ne craignaient rien.

Voltaire, Dictionnaire philosophique, 1764, p. 41 
'So the victors and legislators of the known universe visibly form a society of men that fear nothing.'

Here the speaker presents a series of arguments, which serve him as evidence enabling him to reach a certain conclusion: César dit que la mort n'est rien, que c'est un moment plus heureux que fatal. ('César says that death is nothing, it is a happy rather than a fatal moment'.)

From this evidence, it is manifest that these men fear nothing, conclusion which is reinforced by the adverb visiblement. The relationship of deduction between the evidence and the conclusion is marked by the coordinating conjunction donc, and the adverb serves to emphasize that the speaker assumes the relationship between the evidence and the conclusion to be evident, and that they should be admitted as such by the interlocutor. The adverb can be omitted without any loss in meaning. It both highlights, and reinforces the deductive relationship between the evidence and the conclusion, and the speaker presents the interlocutors as being in agreement with him.

As we have pointed out, in the second half of the $20^{\text {th }}$ century, especially in an oral context, visiblement can be found with pragmatic usage, occasionally accompanied by the adverb oui.

34. Être gaulliste, aimer de Gaulle comme nous l'aimons c'est visiblement pour lui le comble de l'inacceptable. Visiblement oui, puisque ses traits en sont altérés. [Commentaire de François Mitterand: « Je crois que vous exagérez. Je n'ai pas une telle passion »]

Mauriac Claude, L'Oncle Marcel, 1988, p. 273

'Being a De Gaulle supporter or loving De Gaulle as we loved him, was visibly totally unacceptable to him. This was visibly the case as his facial features changed.'

The evidence is still visual, and the adverb reinforces the affirmation oui. According to what I have just seen, I can state that, yes, it is the height of what is considered unacceptable. The evidence here corresponds to «ses traits en sont altérés», which is as if the speaker were saying that, indeed, being a Gaulliste is the height of what is considered unacceptable.

\subsection{The source of $p$ and usage of visiblement $p$}

\subsubsection{The source of $p$}

Mediative or evidential adverbs are adverbs which indicate an outside source. By using them, the speaker signals that the source of information stems from an enunciator or speaker $\mathrm{x}$. This is the case with apparemment, as in the example Apparemment, Air France est en grève or Selon $\mathrm{x}$, or Selon Max, Léa est fâchée. In both these cases we are dealing with a hearsay marker, whereby $\mathrm{p}$ is understood to come from a third party. In the case of Visiblement $\mathrm{p}$, there may well be a source for $\mathrm{p}$, but here, it does not signal an outside source. It is the speaker himself, who signals himself as the source of $p$, and $p$ is presented as being so evident that the whole linguistic community is presented as being in acceptance of $\mathrm{p}$.

Let's refer to Molinier's criterion (2009:12) regarding the usage of the adverb Selon. When we use Selon $N$, the speaker appears to be in agreement with the statement, although he can also explicitly agree with it, or reject it. With apparemment he can agree with it: 
35. Apparemment, les rebelles ont été maîtrisés

'Visibly, the rebels have been overpowered.'

Is this undoubtedly true, or undoubtedly false?

In this case the presence of apparemment is perfectly appropriate and les rebelles ont été maîtrisés is presented as coming from a source outside the speaker. Perhaps he has read about it in the press, or he has heard it on the latest news broadcast. On the other hand, it is not possible to make the same statement with visiblement:

36. ?? Visiblement, les rebelles ont été maîtrisés,?? ce qui est sans doute vrai, ?? ce qui est sans doute faux.

In this case, the speaker assumes statement $\mathrm{p}$, les rebelles ont été maîtrisés, thereby preventing him from stating his own position.

A second criterion serves to confirm that the speaker is indeed the source of $\mathrm{p}$, in visiblement $p$. we could say:

37. Visiblement, selon Paul c'est une erreur.

'Visibly, acording to Paul, it is a mistake.'

The adverb is attributed to the speaker and not to Paul.

But:

38. Selon Paul, visiblement c'est une erreur.

'According to Paul, visibly, it is a mistake.'

This statement is only acceptable if the adverb is attributable to Paul, where he shares the reported discourse. It is Paul who is stating visiblement c'est une erreur.

If the speaker looks through the window and sees a cloudy, grey sky, he could state: Visiblement, il va pleuvoir aujourd'hui. He is basing his statement on visual evidence, the cloudy, grey sky, in order to reach the conclusion that il va pleuvoir. The source of $\mathrm{p}$, of il va pleuvoir aujourd'hui, is the speaker himself. He presents $\mathrm{p}$ as evident and equally accepted by his linguistic community. He could even follow up his initial statement with On ne peut pas dire le contraire, where the linguistic community would be included.

\subsubsection{The usage of Visiblement $\mathrm{p}$}

The use of the adverb visiblement depends on a number of conditions, which will distinguish it from other similar adverbs such as apparemment.

\section{a) Certainty}

We have already mentioned a scale of certainty on which we find adverbs such as peut-être, possiblement, probablement, apparemment, certainement or visiblement. This last term will be at the top of the scale, as it expresses a high degree of certainty. We refer to Ducrot's article (1975:68) regarding je trouve que, which allows for personal judgement. Ducrot (1975:68) shows that with the phrase Je trouve que, there is a possibility of doubt, for example in the phrase Je trouve que tu as été bête et même j'en suis sûr. "L'attitude intellectuelle marquée par trouver comporte une certaine possibilité d'hésitation, et il y a 
donc un degré supérieur de certitude-explicitable par même et par en être sûr." This sequence wouldn't be possible with visiblement:

39. ?? Il est visiblement fâché et même j'en suis sûre.

'He is visibly cross and I am sure about this.'

40. ?? Visiblement il va pleuvoir aujourd'hui, et même j'en suis sûre.

'Visibly, it is going to rain today and I am sure about this.'

By using visiblement, the speaker has sufficient evidence to confirm that $\mathrm{p}$ is true, there is no room for doubt, and that we are at the top of the scale of certainty. It would therefore be redundant to follow this up with et même j'en suis sûr. On the other hand we could state:

41. Il me semble / on dirait qu'il est fâché, et même j'en suis sûre.

'It seems to me / one would say that he is angry, and in fact I am sure of it.'

b) Personal judgement versus reported judgement

Here we will refer again to Ducrot (1975). In order to state visiblement, the speaker has to judge the evidence $\mathrm{x}$ for himself, and this evidence cannot be received indirectly, for instance via hearsay, (as is the case with apparemment).

The judgement has to be personal, even if the speaker does not need to have experienced the fact $\mathrm{p}$ directly. Therefore, in order to state je trouve que le film est intéressant, the speaker needs to have seen the film. On the other hand, with an adverb such as visiblement, the speaker only requires evidence regarding fact $p$, either visual evidence or arguments that he can put forward as proof, in order to draw a conclusion $\mathrm{p}$, by a process of deduction. The speaker can see the queue outside a cinema and state:

42. Visiblement, c'est un bon film.

'Visibly, it is a good film.'

The evidence must be perceived by the speaker himself and cannot be reported to him indirectly, for example via hearsay. If a salesman tells me that the IPad is a wonderful device, I can go and see my interlocutor and tell him:

43. Apparemment, les IPads sont des appareils formidables, c'est le vendeur qui me l'a dit. 'Apparently, iPads are amazing, the sales assistant told me.'

But visiblement would be less appropriate:

44. ?Visiblement, les IPads sont des appareils formidables, c'est le vendeur qui me l'a dit. 'Visibly, iPads are amazing, the sales assistant told me.'

The speaker needs direct perception of the evidence to draw conclusion $\mathrm{p}$. This would usually be visual evidence or arguments that he takes up himself in order to draw a conclusion $\mathrm{p}$, such as:

45. J'envoie toujours mon $\mathrm{CV}$ à cette entreprise et on ne me répond jamais. Visiblement je ne serai jamais pris chez eux.

'I have always sent my CV to this company and they never reply. Visibly, they will never hire me.' 
Where envoyer le $C V$ and ne pas recevoir de réponse is evidence for reaching conclusion $\mathrm{p} j e$ ne serai jamais pris chez eux, evidence for conclusion $\mathrm{p}$, which the speaker takes it upon himself to reach.

c) Contemporaneity of the evidence and the conclusion:

Moreover, this evidence must be contemporaneous at the moment when the speaker reaches conclusion $\mathrm{p}$. This is something that distinguishes visiblement from another marker such as $i l$ paraît que. If I have read a review of a film a month ago and I have a conversation about the film today, I could say:

46. Il paraît que c'est un bon film, j'ai lu une très bonne critique dans les Cahiers du cinéma le mois dernier.

'The film seemed good. I read a very good review in Cahiers du cinéma last month.'

On the other hand, it would be more difficult to say:

47. ?? Visiblement c'est un bon film, j'ai lu une très bonne critique dans les Cahiers du cinéma le mois dernier.

'Visibly, the film is good. I read a very good review in Cahiers du cinéma last month.'

It would be possible, however, if I am in the middle of lying on my sofa reading a review and I tell my interlocutor:

48. Visiblement Juste la fin du monde est un bon film, la critique des Cahiers est très élogieuse.

'Visibly, Juste la fin du monde is a good film. The review in Cahiers du cinéma is full of praise.'

The evidence is contemporaneous at the moment when the speaker draws conclusion $\mathrm{p}$.

\section{$4 \quad$ What about Spanish?}

We have access to a vast corpus with which to reference visiblemente, from medieval times starting from 1300, up until the present day, where the term only appears as a clause element adverb. From 1300 up until 1700, the adverb is often preceded by the verb ver, and from 1600 by the verbs parecer and aparecer.

49. E por ende, la verdad más acompañada fue siempre que la boz de la mentira, assí como lo podréis ver en este fecho visiblemente, con la ayuda de Dios, que en la hora que sean muertos estos falsos, todos los suyos y de su consejo se dividirán y se asconderán por los rincones con muy gran miedo por la falsedad que pensaron, assí como los ladrones,

Libro del cavallero Cifar (1300-1305)

'Finally, the most common truth has always been the voice of lies, as you can see from this fact visibly, with God's help...' 
50. La septima es por ver visiblemente algunas figuras en el tiempo del ayuntamiento con la muger que estaran algunas figuras pintadas cerca dela cama:

Sevillana medicina de Juan de Aviñon; Sevilla:Juan de Burgos, 1545. Madrid Nacional $\mathrm{R} / 30652$ (1381-1418)

'In the seventh picture we can visibly see some figures from the times of the town hall where they are accompanied by a woman. They are shown standing by the bed.'

51. Cinta de talle, que parecía visiblemente de plata.

Lópe de Úbeda, Francisco (1605), La pícara Justina, Antonio Rey Hazas, Editorial Nacional (Madrid), 1977

'A waistband, that seemed to be visibly made of silver.'

As a clause element adverb, it is the equivalent of de manera visible, as we can verify directly by looking at several instances where it is either accompanied by a degree marker such as tan:

52. Después que Leriano acabó de fablarme, quando yo ya quería respondelle, sin aver de mi sueño recordado, soñava que veía a Laureola entrar por la cámara, tan visiblemente como si verdaderamente estoviera despierto, con dessimulada ropa y nueva compañía.

Nuñez Nicolas, Tratado que hizo Nicolás Núñez sobre el que Sant Pedro compuso de Leriano y Laureola llamado Cárcel ... (1416)

'I dreamt that I could see Laureola entering the room, so visibly that it was as if I were awake.'

Or it is paired with another clause element adverb:

53. Rojo tembló súbita y visiblemente, y respondió, siempre temblando, en voz apenas perceptible...

Pardo Bazán, Emilia, (1891) La piedra angular, Biblioteca Virtual Miguel de Cervantes, Universidad de Alicante (Alicante), 2002

'Rojo shook suddenly and visibly and answered, shaking, in a barely audible voice.'

Moreover, from the $19^{\text {th }}$ century onwards, it frequently accompanies subjective adjectives such as agitado, conmovido, disgustado, enojado, etc.

54. El portugués, visiblemente disgustado por aquel sentimentalismo, dejó caer el cuerpo del gato.

Fernández Flórez, Wenceslao (1917-1945), Volvoreta, José-Carlos Mainer, Cátedra (Madrid), 1989

'The Portuguese man, visibly upset by such sentimentality, dropped the body of the cat.'

55. ¡Mentira!- gritó Juanta, visiblemente agitada.

Alarcón, Pedro Antonio de (1852), Relatos, María Dolores Royo Latorre, Unversidad de Extremadura (Salamanca), 1994

' "Lies!”, shouted Juanta, visibly agitated.'

As is the case in French, the speaker draws on contemporary visual evidence to reach conclusion $\mathrm{p}$ : 
56. Paula, por el contrario, enflaquecía visiblemente y perdía por horas el sano color de su cara; pero también aumentaba sus raciones de bizcochos y agua azucarada.

Pereda, José María de, (1871) Tipo y Paisajes, Salvador García Castañada, Ediciones Tantín (Santander), 1989

'Paula, on the other hand, grew visibly thinner, and lost the healthy colour of her face;...'

Nevertheless, in Spanish, in the roughly 1000 instances of the term found on the CORDE database and CREA, there are almost no examples other than its use as a clause element adverb. Up until 1900 there is hardly any doubt that the adverb functions as a clause element adverb. From the second half of the $20^{\text {th }}$ century we can find a few rare examples where visiblemente could be considered as a disjunct adverb:

57. Dicho esto, volvió a reanudarse la partida de tenis, pero resultaba que visiblemente era el criado el mejor de los jugadores, por lo que temiendo tal vez Jehoel y el joven Hugo De Charlotteville quedar humillados delante de nosotros, ofrecieron una raqueta a Saturnino, mientras ordenaban al criado que se retirase.

Herrara Petere, José, (1940), Nieble de cuernos, Jesús Gálvez; José Esteban, Edicós do Castro (La Coruña), 2002

'Having said this, he went back to his tennis match, but the servant was visibly the best player'

Luis Santos Ríos, in his Diccionario de partículas (2003), pays special attention to the use of the term as a clause element adverb, as in the example Ha mejorado visiblemente, (Trad. He is visibly better) but he also includes its usage as a disjunct adverb, as in the example, Visiblemente, se encontraba muy cansado.(Trad. He was visibly tired).

The role of visiblement as a clause element adverb is very similar in both French and Spanish. However, we have seen how in French, from the $17^{\text {th }}$ century onwards and especially from the $18^{\text {th }}$ century, it gains strength as a disjunct adverb. Finally, by the end of the $20^{\text {th }}$ century its tendency towards being used as a disjunct adverb is complete, as we can see in the oral corpora. Yet in Spanish, the adverb is almost always a clause element adverb. This is why we do not translate visiblement from contemporary French as visiblemente in Spanish. So which adverbs could be the Spanish equivalents?

Por lo visto is not possible for two main reasons. Firstly, it is an adverbial phrase that implies a third person. In other words, when the speaker states por lo visto, he is signalling that the source of the information does not come from him, but from someone else, (stated or otherwise).

58. Por lo visto, Pedro se va a vivir a Suiza (me lo ha dicho su hermana).

'Apparently, Pedro is going to live in Switzerland (his sister told me).'

Moreover, the past participle visto here suggests that the evidence is in the past, as opposed to visiblement in French, which requires that the evidence be contemporaneous with conclusion p.

In the phrase por lo visto Pedro se va a vivir a Suiza, the evidence, here the word of the other speaker, is previous to the conclusion Pedro se va a vivir a Suiza. Por lo visto could be the 
equivalent of apparemment in French as a hearsay marker. In addition, the speaker distances himself from what he is stating, and as Elisa Gonzalez Ramos (2005) shows, it can be used ironically or when the speaker clearly wishes to distance himself from $\mathrm{p}$. In contrast, we have seen that visiblement, rather than attenuating $\mathrm{p}$, serves to reinforce it.

Another possibility could be Al parecer, but here again, the source of information comes from another speaker and the speaker detaches himself. It is also a hearsay marker with an element of distancing. The French equivalent would be apparemment or il semblerait que, il paraît que.

The best translations of visiblement would usually be por lo que se ve, es evidente or está claro. Por lo que se ve, as with visiblement, implies that there is some contemporary evidence of conclusion p. Moreover, the source of the information comes from a speaker who would be able to deduce $\mathrm{p}$ from visual evidence.

59. Para la boda de doña Elena, por lo que se ve, no ha hecho falta acudir a la socorrida lista de bodas. Alquilados un par de locales, desde hace ya varias semanas, todo está dispuesto para continuar almacenando regalos. Hasta el momento, cinco Ecus de la Fábrica Nacional de moneda y timbre; una vajilla que la Diputación de Sevilla ha encargado a Victorio y Luchino; una réplica de la diosa Atenea; un reloj marino de mesa del Ayuntamiento de Cádiz; una reproduccón de las "Tablas Alfonsinas" del arzobispo de Sevilla; una cristalería del Centro Nacional del Vidrio;

El Mundo, 15/03/1995: Previa. Boda Infanta Elena y Jaime Marchalar. Sin cursillos prematrimoniales

'For Doña Elena's wedding, as far as one can see, it was necessary to have a wedding list'

\section{Conclusion}

To conclude, we can say that visiblement is an inferential marker, whose source is the speaker himself, including the linguistic community. The adverb stems from direct perception of evidence which allows the deduction of a conclusion $\mathrm{p}$. It reinforces the inductive relationship linking the evidence to the conclusion, allowing the adjoining conclusion to be reinforced. Like several adverbs, it has undergone a process of evolution, not only semantic evolution - it is used to highlight visual evidence in order to support conclusion $\mathrm{p}$, allowing the presentation of arguments as evidence from which one can draw a conclusion $\mathrm{p}$ by an inductive process but a categorical evolution too. At first it was used as a clause element adverb, before being used as a disjunct adverb from the $17^{\text {th }}$ century onwards. Eventually, it goes on to appear by itself, or, accompanying an affirmative, like oui, in the $20^{\text {th }}$ century. The adverb undergoes a process of grammaticalization, as described by Traugott $(1982,1989)$, or of pragmaticalization as described by Dostie (2004), with the adverb becoming more subjective, going from a literal sense, whereby the evidence can only be visual, to a disjunct or pragmatic adverb, where the visual evidence, though still present, loses strength, giving way to a more semantic, deductive meaning. In addition, the adverb becomes more flexible, no longer necessarily in clause-medial position, it can shift to the beginning of the sentence (sentenceinitial), or indeed stand lone (absolute position). 
Regarding translation into Spanish, we have established that a modern translation of visiblement would not be visiblemente when the word is used as a disjunct adverb. A much better translation would be por lo que se ve. We have noted that Spanish has a tendency to use an adverbial phrase where there is a pragmatic adverb in French, often in a detached position: Apparemment/Por lo que parece, por lo visto, Visiblement/por lo que se ve, and also Décidément!/;Desde luego!; Justement!/;Por eso mismo!. The French adverbs have taken on a pragmatic-enunciative quality, which can be seen in their more subjective meaning, as well as in their syntactic position. On the other hand, their Spanish equivalents are at an earlier stage both semantically as well as syntactically. We are reminded that visiblemente in Spanish is used mainly as a clause element adverb. The evolution of these evidential adverbs has taken place at different speed in both languages, which can be a source of confusion for translators. Through a detailed linguistic and diachronic study of these discourse markers, and by comparing them, we have shed new light on their semantic and syntactic role.

\section{Corpora, websites and CD-Roms:}

Corpus de la littérature médiévale en langue d'oül. Cd-Rom, Champion électronique. (2001)

Dictionnaires des XVI et XVII siècles, Paris, Champion électronique (1998).

L'Atelier historique de la langue française. L'histoire des mots du haut Moyen âge au $X I X^{e}$ siècle (1999), Marsane, éd. Redon.

Littré É., (1863-1877 = 2004), Dictionnaire de la langue française, Versailles, Encyclopaedia Britannica France, (6 vols +1 supl.). (L'édition numérisée de L'Atelier Historique est de 1872).

www.frantext.fr, développé par le CNRS-ATILF (Analyse et traitement informatique de la langue française) et l'Université de Nancy2.

La base du Moyen Français: http://zeus.atilf.fr/dmf.htm

La base du Français médiéval: http://zeus.atilf.fr/bfm.htm

CLAPI. http://clapi.univ-lyon2.fr

\section{References}

Anscombre, Jean-Claude (2005): «Le ON-locuteur: une entité aux multiples visages ». In: Bres, Jacques/Haillet, Pierre-Patrick/Mellet, Sylvie/Nølke, Henning/Rosier, Laurence (eds.): Dialogisme et polyphonie: approches linguistiques. Bruxelles, De Boeck-Duculot: 75-94.

Anscombre, Jean-Claude et al. (2009): « Apparences, indices et attitude du locuteur: le cas de apparemment ». Langue française 161: 39-58.

Briz, Antonio (2008): Diccionario de partículas del español. Alicante: Biblioteca Virtual Miguel de Cervantes. http://www.dpde.es/ [ $1^{\text {rst }}$ october 2018]

Dendale, Patrick/Coltier, Danièle (2004): «La modalisation du discours de soi: éléments de description sémantique des expressions pour moi, selon moi et à mon avis». Langue française 142: 41-57.

Dendale, Patrick/Tasmowski, Liliane (eds.) (1994): «Les sources du savoir et leurs marques linguistiques ». Langue française 102.

Dendale, Patrick/Van Bogaert, Julie (2007): “A semantic description of French lexical evidential markers and the classification of evidentials". Rivista di Linguistica 19: 65-90. 
Ducrot, Oswald (1975b): «Je trouve que ». Semantikos, vol. 1: 63-88.

Ducrot, Oswald (1995): «Les modificateurs déréalisants ». Journal of pragmatics 24: 145165.

Gonzalez Ramos, Elisa (2005): «Por lo visto y al parecer: comparación de dos locuciones modales epistémicos de evidencialidad en español actual ». Interlingüística 16: 541-554

Guentchéva, Zlatka (1996): L'énonciation médiatisée. Louvain, Paris: Peeters.

Hassler, Gerda (2014): «Adverbes épistémiques dans le français parlé et écrit: apparemment, évidemment, visiblement, éventuellement, probablement ». In: Weidenbusch, Waltraud (ed.): Diskursmarker, Konnektoren, Modalwörter. Tübingen, Narr: 161-174.

Kronning, Hans (2003): «Modalité et évidentialité ». In: Birkelund, Merete/Boysen, Gerhard/Kjaersgaard, Poul Søren (eds.): Aspects de la Modalité. Tübingen, Max Niemeyer : 131-151. (= Linguistische Arbeiten 469)

Molinier, Christian (2009): «Les adverbes d'énonciation: comment les définir et les sousclassifier ». Langue française 161: 9-22.

Rodríguez Somolinos, Amalia (2010): "L'évolution de apparemment en français: la formation d'un marqueur d'attitude énonciative». In: Combettes, Bernard/Guillot, Céline/Prévost, Sophie/Oppermann-Marsaux, Evelyne/Rodríguez Somolinos, Amalia (eds.): Le changement en français. Etudes de linguistique diachronique. Bern, Lang: 345361.

Santos Rios, Luís (2003): Diccionario de partículas. Luso-española ediciones.

Traugott, Elizabeth (1982): "From propositionnal to textual and expressive meanings: some semantic-pragmatic aspects of grammaticalization". In: Lehmann, Winfred/Malkiel, Yakov (eds.): Perspectives on Historical Linguistics. Amsterdam, Benjamins: 45-271.

Traugott, Elizabeth (1989): "On the rise of epistemic meanings in English: an example of subjectification in semantic change". Language 57: 33-65. 